\title{
Kajian Teknik Pengendalian Rute Circuit Switching Pada Jaringan Telekomunikasi Berbasis Simulasi
}

\author{
Tatang Rohana \\ Teknik Informatika \\ Universitas Buana Perjuangan Karawang, Indonesia \\ tatang.rohana@ubpkarawang.ac.id
}

\begin{abstract}
Abstrak-Routing dimaksudkan untuk memperoleh konfigurasi jaringan optimum yang diperlukan dalam menangani trafik secara sistematis dan efisien. Sasaran utamanya adalah menentukan semua rute yang merupakan bagian dari jaringan telekomunikasi berdasarkan ketentuan dan petunjuk yang disepakati untuk menjamin terlaksananya suatu koneksi secara cepat. Penelitian ini berisi tentang kajian teknik perutean yang merupakan bagian dari circuit swithing, yaitu Alternate Hierarchical Routing (AHR) dan Dynamic Nonhierarchical Routing (DNHR). Dalam AHR, berbagai alternatif perutean didefinisikan sebagai lintasan Routing. Mekanisme perpindahan trafik ke rute alternatif didasarkan pada overflow dari trafik yang diprioritaskan, sedangkan DNHR keputusan pemilihan rute didasarkan pada tabel dinamik yang merupakan fungsi waktu. Metode penelitian yang digunakan adalah metode kajian pustaka dan metode pengujian. Metode pengujian digunakan sebagai alat bantu terhadap perhitungan dan analisa secara pustaka. Penilaian performansi teknik perutean yang dikaji diukur dari keefektifan dan efisiensi dalam penentuan rute trafik, trafik yang ditemukan, dan efisiensi waktu pencarian rute trafik. Berdasarkan hasil pengujian yang sudah dilakukan pada penelitian ini, diperoleh hasil bahwa berdasarkan jumlah rute yang ditemukan teknik Alternate Hierarchical Routing lebih efektif dibandingkan teknik Dynamic Nonhierarchical Routing. Sedangkan berdasarkan efisiensi waktu pencarian trafik, teknik Dynamic Nonhierarchical Routing lebih efisien $5.55 \%$ dibanding teknik Alternate Hierarchical Routing.
\end{abstract}

Kata kunci — Perutean, Jaringan Interkoneksi. AHR, DNHR, Simulasi

\section{Pendahuluan}

\section{A. Latar Belakang}

Perutean (Routing) dalam telekomunikasi merupakan hal yang penting karena akan berdampak pada teknologi, kualitas trasnmisi, kecepatan transmisi, bahkan terhadap regulasi telekomunikasi.Perutean dimaksudkan untuk memperoleh konfigurasi jaringan yang optimum yang diperlukan utuk menangani trafik secara sistematis dan efisien. Routing juga berkaitan dengan proses dan penggunaan rute, berdasarkan suatu aliran tertentu dan akan berakhir ketika pesan atau panggilan telah mencapai lokasi tujuan. Sasaran utamanya adalah menentukan semua rute yang merupakan bagian dari jaringan telekomunikasi berdasarkan ketentuan - ketentuan dan petunjuk yang disepakati untuk menjamin terlaksananya hubungan secara cepat dengan mutu yang memenuhi syarat, tanpa mengabaikan efisiensi dalam penggunaan fasilitas jaringan. Routing memanfaatkan karakteristik yang sebaik - baiknya dari komponen jaringan, terutama dengan berkembangnya teknologi baru seperti penyambungan digital, transmisi digital, satelit, serat optik, dan lain - lainnya. Definisi dari perutean (Routing) adalah proses atau teknik yang dipergunakan untuk meningkatkan kinerja jaringan komunikasi, sehubungan dengan kondisi trafik yang melewati jaringan tersebut. Beberapa teknik yang digunakan dalam pengendalian rute (raouting) pada sistem komunikasi adalah:

a) Pada sirkuit switching dikenal direct Routing, Alternate Hierarchical Routing, (AHR) dan Dynamic Nonhierarchical Routing (DNHR)

b) Pada paket / message switching dikenal fixed Routing, flooding, adaptive distributed Routing, dan adaptive centralized Routing.

Pada AHR, barbagai alternatif rute berdasarkan hirarki sentral didefinisikan sebagai lintasan rute. Mekanisme perpindahan trafik ke rute - rute alternatif didasarkan pada overflow dari trafik pada rute yang lebih diprioritaskan. Sedangkan pada DNHR, keputusan pemilihan rute didasarkan pada tabel dinamik yang merupakan fungsi waktu dan mengacacu pada hasil pengukuran trafik melalui jaringan signalling. Perutean pada paket / message switch yang berdasarkan pada teknik fixed Routing adalah rute yang secara permanen dipilih. Teknik flooding pada Routing paket / message switch sama sekali tidak didasarkan pada informasi mengenai jaringan. Teknik Routing flooding bekerja dengan cara paket yang akan dikirim akan dibroadcast ke semua node yang terhubung ke pengirim, kemudian dari setiap node tersebut paket akan terus dikirim ke setiap node yang lain kecuali ke node yang mengirimkan sebelumnya.

Begitulah mekanisme selanjutnya sampai paket tersebut diterima oleh tempat tujuan. Pada penelitian ini penulis mengambil topik mengenai pengendalian rute pada teknik perutean circuit switching, yaitu AHR dan DNHR (DNHR). Pada penelitian ini, dikaji mengenai performansi dari kedua teknik pengendali rute yang didasarkan pada efisiensi pencarian rute trafik, jumlah trafik yang ditemukan, dan waktu efisiensi pencarian rute trafik. Untuk mendukung kajian teknik pengendalian rute ini, dibuat program simulasi untuk menganalisa data - data yang akan dibandingkan tingkat performansinya antara teknik AHR dan DNHR. Kasus kajian teknik perutean ini diimplementasikan pada jaringan telepon atau panggilan telepon yang berinterkoneksi

B. Tujuan Penelitian

Tujuan dari penelitian ini adalah: 
a) Mengimplementasikan teknik pengendalian rute yang merupakan bagian dari jaringan telekomunikasi berdasarkan ketentuan - ketentuan dan petunjuk yang disepakati oleh standar nasional, internasional, maupun regulasi telekomunikasi.

b) Menggunakan dan menganalisa teknik pengendalian rute circuit switching dengan AHR maupun dynamic Nonhierarchiccal Routing pada sistem telekomunikasi khususnya masalah perutean dengan menggunakan kedua teknik Routing tersebut.

c) Mengimplementasikan skema AHR maupun dynamic nonhierarchiccal Routing pada sistem perutean.

d) Dapat menentukan kelebihan dan kekurangan dari AHR maupun dynamic nonhierarchiccal Routing guna meningkatkan performansi sistem perutean dari hasil pengujian yang selanjutnya menjadi bahan analisa

\section{Manfaat Penelitian}

Manfaat dari penelitian ini adalah

a) Hasil penelitian ini diharapkan menjadi bahan masukan atau referensi sehingga sistem ini menjadi acuan dan prototype model perutean (Routing) bidang telekomunikasi untuk para peneliti lainnya.

b) Penelitian ini diharapkan menjadi model kajian alternatif, yang menggabungkan kajian pustaka dengan pengujian teknik, metode atau model suatu teori yang memerlukan uji coba sebagai alat pembuktian suatu teori.

\section{Metodologi Penelitian}

Dalam penelitian ini metode yang digunakan adalah kolaborasi dari metode penelitian kajian pustaka dan metode pengujian. Kajian pustaka dilakukan dengan cara mengumpulkan data - data yang berhubungan dengan permasalahan yang ada melalui tulisan atau jurnal ilmiah, buku - buku pendukung, maupun bentuk yang lainnya. Dengan metode kajian pustaka didapat rumusan data - data hasil evaluasi yang secara teori benar terhadap hasil pengujian yang dilakukan. Selain dengan melakukan kajian pustaka, peneitian ini juga menggunakan metode pengujian yang besifat sebagai pendukung terhadap perhitungan dan analisa secara teori. Pada metode penelitian pengujian ini, dikembangkan suatu program viasualisasi sederhana sebagai alat bantu untuk mendapatkan data - data hasil uji.

Data hasil uji yang diharapkan adalah bagaimana cara penentuan rute trafik yang dipilih sesuai dengan kondisi jaringan telekomunikasi yang ada oleh suatu terminal pengirim untuk mengirimkan informasi samapai diterima dengan baik oleh terminal penerima. Dalam simulasi pengujian ini, diberikan suatu asumsi bahwa pemilihan trafik panggilan telepon pada jalur kosong (tidak sibuk). Data hasil pengujian berupa pemilihan rute yang efisien berdasarkan kondisi waktu dan keadaan jaringan yang ada, nantinya dipakai sebagai acuan untuk menentukan rute dan teknik yang tepat dalam pelaksanaan Routing pada jaringan interkoneksi telekomunikasi.

\section{HASil PEnElitian DAN Pembahasan}

\section{A. Pembuatan Model Simulasi}

Membuat suatu model yang tepat adalah salah satu keberhailan dari penelitian in, sentral - sentral yang membentuk suatu jaringan telepon dianalogikan dengan model titik - titik koorditat yang mewakili suatu node jaringan telepon yang terinterkoneksi. Pada simulasi perutean ini, model titik node digambarkan berdasarkan pada gerbang sentral antar regional yang ada di Indonesia. Dalam penelitian ini, jumlah gerbang sentral yang digunakakan hanya berjumlah 15 gerbang sentral. Tabel 1 merupakan gerbang sentral yang digunakan.

Tabel 1Daftar Gerbang Sentral

\begin{tabular}{ccc}
\hline No & Nama Gerbang Sentral & Kode \\
\hline 1 & Medan & Mdn \\
2 & Padang & Pdg \\
3 & Palembang & Plm \\
4 & Jakarta & Jkt \\
5 & Bandung & Bdg \\
6 & Semarang & Smr \\
7 & Surabaya & Sby \\
8 & Denpasar & Dpr \\
9 & Ujung Pandang & Ujp \\
10 & Banjarmasin & Bjm \\
11 & Ambon & Amb \\
12 & Samarinda & Smd \\
13 & Mataram & Mtm \\
14 & Pontianak & Ptk \\
\hline
\end{tabular}

Gerbang sentral tersebut meliputi Medan, Padang, Palembang, Jakarta, Bandung, Semarang, Surabaya, Denpasar, Ujung Pandang, Banjarmasin, Ambon, Samarinda, Mataram, Pontianak, dan Jayapura. Gambar 1 adalah node - node gerbang sentral yang berinteraksi antar sentral yang satu ke sentral berikutnya. 


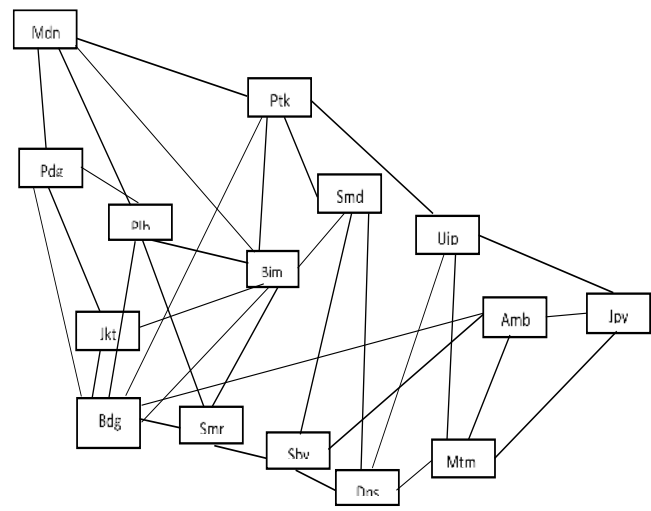

Gambar 1 Jaringan Gerbang Sentral Antar Regional yang Berinterkoneksi

Pada model Gambar 1 akan diproses dengan dua teknik yang berorientasi pada waktu dual dan sistem dual yang dilakukan secara acak. Kasus yang pertama misalkan akan dibuat koneksi antara sentrak Bandung ke sentral Medan. Apabila koneksi tersebut dibuat dengan teknik AHR, maka akan terlihat seperti Gambar 2.

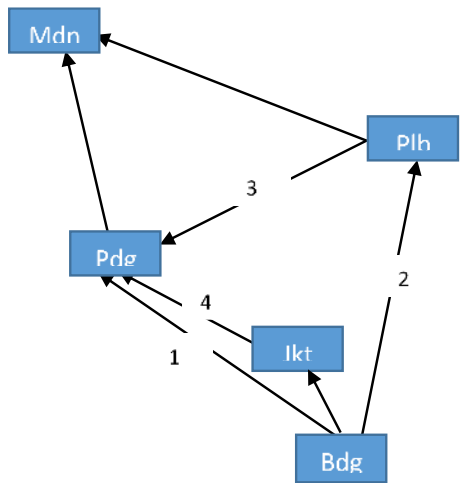

Gambar 2 Rute Trafik dengan Teknik AHR

Seperti yang sudah dijelaskan sebelumnya, pada teknik AHR berbagai alternatif rute trafik didasarkan pada hirarki sentral yang didefinisikan sebagai lintasan rute. Penentuan rute trafik yang dipilih didasarkan pada hirarki jalur yang sudah diprioritaskan berdasarkan jarak terdekat dari masing - masing gerbang sentral. Pada kasus seperti Gambar 2, maka rute trafik yang terbentuk dapat dilihat berdasarkan urutan trafik yang dipilih seperti pada Gambar 3 .

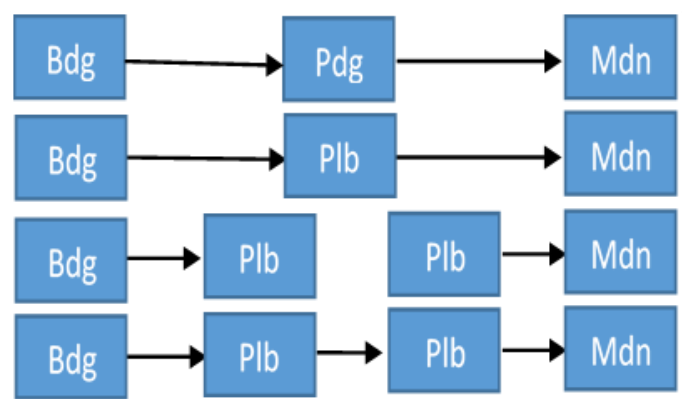

Gambar 3 Jalur yang Terbentuk Berdasar AHR

Jadi berdasarkan teknik AHR, pemilihan rute trafik akan dilakukan secara hirarki. Jika menemukan trafik yang sibuk, maka pemilihan rute berikutnya didasarkan pada trafik yang diprioritaskan berikutnya, sampai ditemukan trafik yang kosong. Akan tetapi jika menggunakan teknik DNHR, pemilihan rute trafik dilakukan lebih dinamis, pemilihan trafik akan dilihat berdasarkan jalur trafik yang kosong pada saat itu seperti yang ditunjukkan pada Gambar 4..

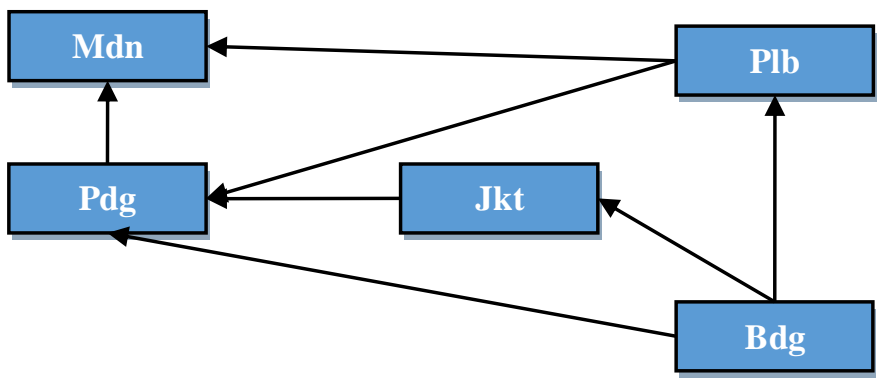

Gambar 4 Rute Trafik dengan DNHR 
Jadi dengan teknik DNHR maka hasil yang diperoleh tidak lagi berdasarkan rute trafik yang diprioritaskan seperti AHR, tetapi trafik yang dipilih bisa diambil secara random dari gerbang sentral asal ke gerbang sentral tujuan melalui rute - rute yang kosong pada saat itu.

Untuk melengkapi hasil penelitian, maka dibuat suatu program simulasi yang menggambarkan bagaimana kedua teknik perutean yang dikaji ini bekerja. Simulasi ini dibuat untuk memperoleh gambaran tingkat perbedaan cara pencarian rute trafik antara teknik AHR dan DNHR. Dalam porgram simulasi tersebut, masing - masing gerbang sentral antar kota dihubungkan dengan garis yang menyatakan adanya jalur koneksi trafik.

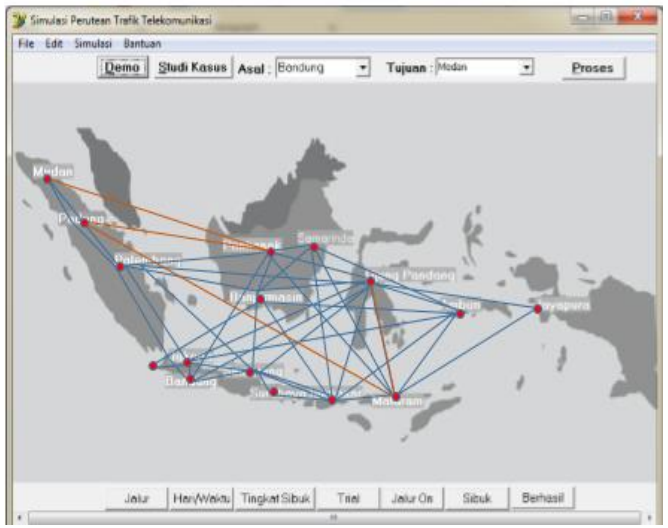

Gambar 5 Model Tampilan Program Simulasi Perutean

Pada Gambar 5, masing - masing kota yang menyatakan gerbang sentral terkoneksi dengan garis berwarna biru dan warna merah. Garis warna biru menyatakan jalur trafik sedang kosong pada saat itu, sedangkan garis merah menyatakan trafik sedang dalam kondisi sibuk. Dalam simulasi ini jumlah gerbang sentral dan tingkat kesibukan dapat diatur sesuai dengan yang diinginkan, pengaturannya dapat dilihat pada Gambar 6.

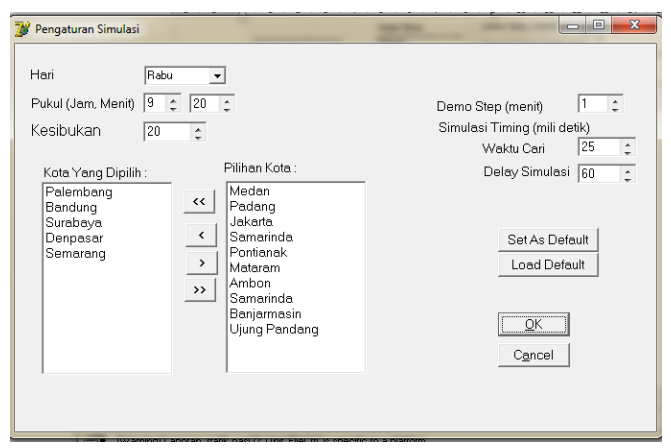

Gambar 6 Pengaturan Sentral

Tampilan akhir dari proses simulasi adalah berbentuk laporan yang memberikan informasi seberapa jauh performansi dari masing - masing teknik perutean, baik AHR maupun DNHR. Laporan seperti yang ditunjukkan pada Gambar 7 ditampilkan setiap kali pengujian terhadap simulasi rute yang dilakukan dilakukan.

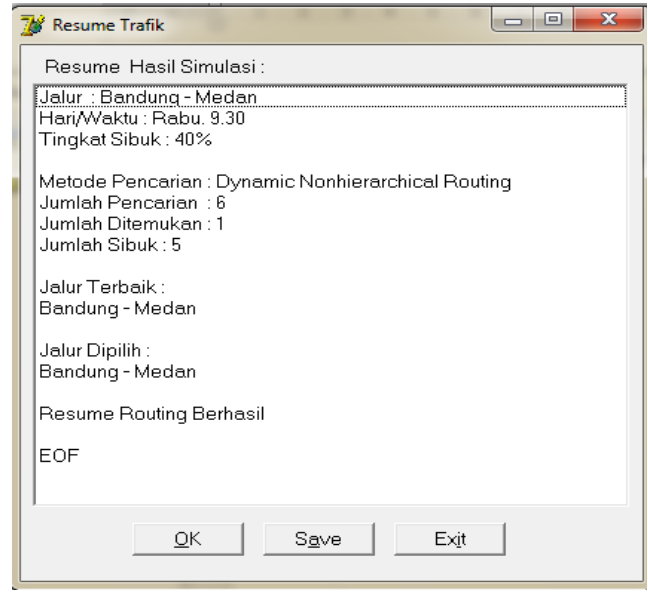

Gambar 7 Laporan Proses Simulasi Trafik 


\section{B. Pengujian Teknik AHR dan DNR}

\section{Analisa Berdasarkan Jumlah Trafik yang Ditemukan}

Langkah pengujian yang pertama adalah membandingkan dari aspek jumlah trafik (jalur) yang ditemukan baik AHR maupun DNHR. Berdasarkan hasil pengujian, kedua teknik memiliki perbedaan yang cukup signifikan, walaupun untuk beberapa kasus pengujian perbedaannya relatif lebih kecil.

\begin{tabular}{|c|c|c|c|c|c|}
\hline \multirow[t]{2}{*}{$\begin{array}{l}\text { Waktu } \\
\text { (mdetik) }\end{array}$} & \multicolumn{2}{|c|}{$\begin{array}{l}\text { Jumlah Jalur } \\
\text { Yang Dicari }\end{array}$} & \multirow{2}{*}{$\begin{array}{c}\text { Kesibukan } \\
(\%)\end{array}$} & \multicolumn{2}{|c|}{$\begin{array}{c}\text { Jumlah } \\
\text { Jalur Yang } \\
\text { Ditemukan }\end{array}$} \\
\hline & AHR & DNHR & & & \\
\hline 5 & 1 & 1 & 10 & 1 & 1 \\
\hline 15 & 1 & 10 & 25 & 1 & 1 \\
\hline 25 & 8441 & 9 & 50 & 604 & 1 \\
\hline 50 & 18867 & 15 & 75 & 122 & 1 \\
\hline 100 & 34690 & 34334 & 90 & 0 & 0 \\
\hline
\end{tabular}

Berdasarkan terlihat berdasarkan jumlah jalur yang dicari dan jalur data yang ditemukan, teknik AHR memiliki jumlah trafik yang lebih besar dibandingkan dengan teknik DNHR. Sehingga dari sisi pencarian jalur dan jumlah jalur yang ditemukan teknik AHR lebih baik.

Tabel 3 Perbandingan Total Rata - Rata Trafik yang Dicari

\begin{tabular}{ccc}
\hline $\begin{array}{c}\text { Waktu } \\
\text { Jata-Rata }\end{array}$ & AHR & DNhah \\
\hline 39 & 12400 & 6873.8 \\
\hline
\end{tabular}

Berdasarkan Tabel 3, teknik perutean dengan aturan DNHR memberikan performansi yang cukup berbeda dibandingkan dengan teknik AHR. Hal ini terjadi karena:

a) Model AHR merupakan teknik Routing yang melakukan pencarian berdasarkan trafik yang diprioritaskan, dengan prioritas jarak yang lebih dekat antara satu sentral ke sentral yang lainnya. Sehingga teknik AHR ini akan menampilkan jumlah jalur koneksi yang lebih banyak karena semua jalur koneksi akan dicobanya.

b) Skema teknik DNHR memiliki keteraturan cara pencarian, karena teknik ini melakukan pencarian berdasarkan jalur yang diacak (random) dari jalur koneksi yang tersedia. Bila menemukan jalur yang kosong akan langsung ditapilkan dan proses pencarian akan dihentikan, proses kerja teknik DNHR tidak berdasarkan pada jalur koneksi yang diprioritaskan. Sehingga, jalur koneksi yang ditampilkannya akan lebih sedikit dibandingkan teknik AHR, tetapi waktu pencariannya lebih cepat

2. Analisa Berdasarkan Waktu Efisiensi Trafik

Data pengujian berikutnya yang dianalisis adalah efisiensi waktu trafik dari kedua teknik tersebut, baik AHR maupun DNHR. Pengujian dilakukan terhadap beberapa sentral telpon dengan waktu dan hari koneksi yang sama yaitu hari Sabtu jam 12.00, dengan rasio rata -rata kesibukan $10 \%$. Jumlah sentral yang diuji masing - masing berjumlah 5, 9, 10,12 , dan 15.

Tabel 4 Perbandingan Waktu Efisiensi Trafik

\begin{tabular}{|c|c|c|}
\hline \multirow{2}{*}{$\begin{array}{c}\text { Jumlah Sentral } \\
\text { Uji Coba }\end{array}$} & \multicolumn{2}{|c|}{ Waktu Efisien Trafik } \\
\hline & AHR (mdetik) & DNHR (Mdetik) \\
\hline 5 & 60 & 50 \\
\hline 9 & 100 & 100 \\
\hline 10 & 100 & 100 \\
\hline 12 & 120 & 110 \\
\hline 15 & 160 & 150 \\
\hline
\end{tabular}

Berdasarkan Tabel 4, dari aspek waktu efisiensi pencarian, teknik pengendalian rute DNHR memiliki waktu yang lebih baik dibandingkan dengan AHR walaupun perbedaannya tidak signifikan. Data perbandingan waktu efisiensi pencarian trafik dapat dilihat juga secara grafik yang ditunjukkan pada Gambar 8. 


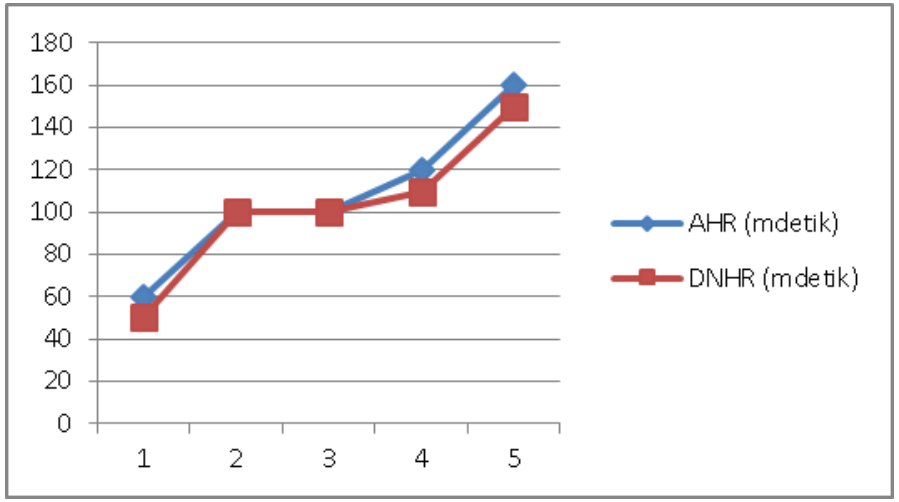

Gambar 8 Grafik Perbandingan Waktu Efisiensi Pencarian Trafik

Kalau dirata - ratakan perbandingan efisiensi waktu pencarian trafik ditunjukkan pada Tabel 5.

Tabel 5 Rata - Rata Waktu Pencarian Trafik

\begin{tabular}{ccc}
\hline $\begin{array}{c}\text { Jumlah Sentral } \\
\text { Yang Diuji }\end{array}$ & \multicolumn{2}{c}{ Total Rata - Rata Waktu Pencarian } \\
AHR (mdetik) & DNHR (mdetik) \\
\hline $5-15$ & 108 & 102 \\
\hline
\end{tabular}

Kalau dihitung seberapa baik performansi efisiensi waktu pencarian trafik antara teknik AHR dan DNHR dapat dihitung dengan Persamaan 1.

\begin{tabular}{|c|c|}
\hline \multirow{2}{*}{ Performansi $=$} & Efisiensi AHR - Efisiensi DNHR \\
\hline & Efisiensi AHR \\
\hline \multirow{2}{*}{ Performansi = } & 108-102 \\
\hline & 108 \\
\hline$=$ & $5.55 \%$ \\
\hline
\end{tabular}

Dengan demikian berdasarkan performansi waktu efisiensi pencarian, teknik DNHR memberikan nilai yang lebih baik dibandingkan dengan teknik AHR.

\section{KESIMPULAN DAN SARAN}

Setelah melakukan pengujian dan analisis dari kedua teknik Routing (perutean) yaitu AHR dan DNHR, maka sampailah pada pembahasan akhir yaitu kesimpulan dan saran.

A. Kesimpulan

a) Berdasarkan hasil penelitian yang telah dilakukan tetang kajian teknk Perutean (Routing), penilaian kinerja teknik Routing dapat dinilai berdasarkan waktu pencarian, jumlah jalur (trafik) yang ditemukan, dan waktu efisiensi trafik.

b) Berdasarkan jumlah trafik atau jalur yang ditemukan, teknik AHR memiliki performansi yang lebih baik dibandingkan dengan teknik DNHR.

c) Berdasarkan efisiensi waktu pencarian rute trafik, DNHR lebih baik dibandingkan teknik AHR, dengan nilai efisiensi mencapai $5.55 \%$

B. Saran

a) Untuk pengembangan lebih lanjut, jumlah gerbang sentral dalam simulasi bisa ditambahkan, supaya hasil pengujian lebih akurat.

b) Perlu dilakukan penelitian untuk menentukan lintasan (trafik) dengan teknik - teknik lain selain AHR maupun DNHR yang kemudian dapat dibandingkan juga kelebihan dan kelemahan tiap teknik tersebut.

c) Perlu dilakukan penelitian untuk parameter - parameter yang lebih lengkap, seperti jarak, waktu pencarian, dan parameter lainnya.

\section{PENGAKUAN}

Penelitian ini dibuat sebagai salah satu kewajiban Tri Darma Perguruan Tinggi Penulis sebagai seorang Dosen. Penelitian ini dilaksanakan secara mandiri.

\section{DAFTAR PUSTAKA}

[1] Iqbal, Muhammad, "Implementasi Common Channel Signalling (CCS7) Untuk Jaringan Telekomunikasi", Seminar dan Call Papper Munas Aptikom, Politeknik Telkom Bandung, 2010. 
[2] Karthikeyan, V. \& Vijayalakshmi, V.J,: "Improving The Scalability By Contact Information CompressionIn Routing, International Journal on Information Theory (IJIT), Vol.2, No.1/2/3/4, 2008

[3] Krishan, Prashant, "Comparisson and Performance Analysis of Dynamic and Static Clustering Based Routing Schema in Wireless Sensor Network", International Journal of Advanced Research in Computer \& Communication, Vol. 2. Issue No.4, 2013.

[4] Manfield, David R, "Performance Analysis of SS7 Congestion Controls Under Sustained Overload", Ieee Journal On Selected Areas In Communications, Vol. 12, No. 3,1994

[5] Mohan, Kadali et all, "Overview of CCS7 Signalling", International Journal Computer Technology \& Application Vol. 3(6), 1954-1958, 2012

[6] Pasaribu, Thalib, "The Way of CalculatingThe Traffic And Signalling Network Dimention of Comman Channel Signalling (CCS7)", Jurnal Sistem Teknik Industri Volume 7, No. 2, 2006.

[7] Sneppe, Manfred, "Circuit Switching Versus Paket Switching”, International Journal of Open Information Technology ISSN: 2307-8162 Vol. 3 No.4, 2015.

[8] Suharyadi, Hasan, "Kajian Tentang Perbandingan Performansi Ccs 7 Dan Sistem R2 Signaling Pada Sistem Telekomunikasi Di PT. Telkom “, Laporan Tugas Akhir, 2010. 